\title{
Gaining Global Clout Through Monetary Union: Evidence from East Africa
}

\author{
Menna Bizuneh \\ Pitzer College, Claremont, United States \\ Steven Buigut \\ American University at Dubai, Dubai, United Arab Emirates \\ Neven Valev \\ Georgia State University, Atlanta, United States
}

\begin{abstract}
Gaining international clout is an important motivation in pursuing monetary integration, as small country merge into a larger entity that can project more global power. We provide evidence to that effect using survey data from Kenya pertaining to public support for the proposed East African Monetary Union. We show that Kenyans prefer a larger union with more members for the purpose of gaining global clout. However, not all potential member countries are equally welcomed. Larger and more stable countries are favored over fragile states.
\end{abstract}

JEL Classifications: F33, E5

Keywords: Monetary Union, International Clout, Optimal Size, East African Community

\footnotetext{
* Corresponding Author: Menna Bizuneh; Pitzer College, Claremont, California 91711, United States, Tel: +1-909-607-9127, E-mail: Menna_Bizuneh@pitzer.edu.

Co-Author: Steven Buigut; American University at Dubai, Sheikh Zayed Road, Dubai, United Arab Emirates, Tel: + 97143999000 , E-mail: SBuigut@aud.edu.

Neven Valev; Georgia State University, 14 Marietta Street, Atlanta, Georgia 30303, United States, Tel: +404 56662 42, E-mail: ntvalev@gmail.com.
}

Acknowledgements: We would like to thank the participants of the Eastern Economic Association and Western Economic Association International's conferences in New York and Santiago, Chile, respectively. Funds provided by Pitzer College supported the work leading to this report in whole or in part. 


\section{Introduction}

While there are several compelling reasons for regional integration, this study argues that gaining international clout is a key reason why countries pursue regional integration. Whalley (1998) points out that European countries started to integrate in the 1950s partly to gain leverage in trade negotiations with the United States, with similar objectives being pursued later by Mercosur. Masson (2006) makes a similar argument for the East African Community (EAC). The European Commission (2014) writes that, "the euro provides a powerful tangible symbol of unity, identity and cooperation," thus "giving Europe a stronger voice and more economic clout in global trade." Andriamananjara and Schiff (2001) and Schiff (2014) formalize these ideas in models where countries join in regional blocs to lower external negotiation costs and to gain international bargaining power.

However, this study does not offer direct empirical evidence that gaining international clout is a motivating factor in the pursuit of regional integration. We provide such evidence using unique survey data from Kenya, which is in the process of joining into a monetary union with the other members of the East African Community. Specifically, we show that Kenyans recognize that a monetary union could raise the international standing of Kenya and that these expectations enhance public support for the union. On the other hand, we also show that people do not equally favor all other potential associates. Specifically, while a larger union is preferred given the objective of international power, adding smaller or more fragile states is less desirable.

We build upon a large body of literature on the economic and political factors underlying monetary unions that includes Feldstein (1997), Frankel and Rose (1998), Rose and Van Wincoop (2001), De Grauwe (2013), and Orphanides (2014), among others. Our contribution is to explore the effect of gaining international power on public support for a monetary union. We also contribute to the studies investigating the optimal size of monetary unions, for example, Maloney and Macmillen (1999) and Forlati (2015), by providing 
evidence that larger unions are preferred but not all potential members are equally welcomed. To our knowledge, no other study has presented evidence on the public preferences over specific countries to be included in a proposed monetary union.

Further, we provide micro level data within a literature that typically approached the question of monetary unification at the macro-level. Frieden et al. (2001) and Blomberg et al. (2005) show that attitudes and preferences over currency policy vary across social groups. The survey data allow us to observe those differences. We can also analyze attitudes toward a policy change in advance of its implementation and, hence, shed light on its potential actual implementation. Finally, we contribute to a relatively scant study on the East African Community and its proposed monetary union (Buigut 2010, Kimenyi and Kuhlman 2012, Lepetit et al. 2015, Nnyanzi et al. 2016, Buigut 2016).

The rest of the paper is organized as follows. Section II discusses the EAC and section III presents the data. In sections IV and V, we discuss our methodology and the estimation results. Section VI concludes.

\section{The East African Community}

The East African Community (EAC) currently comprises six member countries-Kenya, Uganda, Tanzania, Rwanda, Burundi, and South Sudanwith an estimated population of $174.9^{1}$ million in 2015 and an area of 2.46 million $\mathrm{km}^{2}$. South Sudan became a full member only in September 2016. The journey to the current state of integration has been long and tortuous. Attempts to forge an East African Economic bloc by the three founding membersKenya, Uganda, and Tanzania_-dates back to regional co-operation under colonial rule. During 1961 to 1967 they operated under the East African Common Services Organization (EACSO). The first East African Community

${ }^{1}$ Estimates from the World Banks' World Development Indicators. 
(EAC) was established in 1967 to replace the EACSO and lasted until 1977 when socialist leaning Tanzania and capitalist leaning Kenya found it hard to work together and the appearance of the Idi Amin dictatorship in Uganda soured relations with the other members (Goldstein and Ndung'u 2001, Hazlewood 1979). Negotiations to revive the community led to the signing of the tripartite agreement in 1993. Following this agreement, the Treaty for Establishment of the East African Community was signed in November 1999 and came into force in 2000. In 2005, the customs union became operational. At this point it was still a three-member community. Rwanda and Burundi joined in 2007. The East African Common Market came into force in July 2010. An East African Monetary Union (EAMU) protocol was signed in November 2013. The protocol lays groundwork for the process, the prerequisites, and convergence criteria for the eventual implementation of a monetary union in 2024.

Besides forging a deeper and less easily revocable union, the EAMU is expected to lower transaction costs, to help price stabilization, to improve resource allocation across the region, to lead to greater trade integration, and to improve the prospects for greater investment. Several studies (Buigut and Valev 2009, Guillaume and Stasavage 2000) have argued that regional African monetary unions can act as an agent of restraint and deliver more price stability than national central banks. A larger and more cohesive economic bloc may also provide a stronger voice and more economic clout in global negotiations. Negotiating as a monetary bloc in global trade issues (for example, the EUEAC economic partnership agreement recently concluded in 2014) gives it better chances of achieving more favorable deals than when small states act individually. Also, complexity from trade negotiations requires high level of expertise that could be enhanced via regional cooperation, through cost savings and human resource pooling.

Vis-à-vis the EAC, there are two things to note in our survey. First, South Sudan is not included in the study as it was not yet a full member of the union when the survey was undertaken and was therefore not included. Second, preference for inclusion is viewed from the perspective of Kenyan respondents. 
We believe that Tanzania and Uganda are preferred more than the other members based on economic size, political stability, language similarity, proximity, and historical trade relations. Historically, Tanzania, Uganda and Kenya have been involved in the EAC project way back to the colonial era under the British rule. They are also the countries that revived the community in 1993. Rwanda and Burundi are more recent entrants having joined in 2007, after the revived union had progressed to the customs union stage. Within the community, Tanzania and Uganda are Kenya's top trading partners. For example, the International Monetary Fund (IMF) Direction of Trade statistics indicates that in 2015 Kenyan exports to Tanzania and Uganda were 477 million US dollars and 633 million US dollars respectively compared to 82 million US dollars and 179 million US dollars to Burundi and Rwanda, respectively (Table 1). Thus, from an economic perspective, respondents are likely to be swayed in favor of the two countries with which they are more economically integrated. The two countries also bring more in terms of external recognition, as they are the dominant economies in the community, in terms of both GDP and population, alongside with Kenya.

Table 1. GDP, population, and trade

\begin{tabular}{|l|c|c|c|c|}
\hline Country & GDP & Population & $\begin{array}{c}\text { Kenya's } \\
\text { exports }\end{array}$ & $\begin{array}{c}\text { Kenya's } \\
\text { imports }\end{array}$ \\
\hline Kenya & 63.8 & 47.2 & - & - \\
\hline Tanzania & 45.6 & 53.9 & 477.5 & 793.9 \\
\hline Uganda & 27.1 & 40.1 & 633.2 & 427.0 \\
\hline Rwanda & 8.3 & 11.6 & 179.2 & 80.2 \\
\hline Burundi & 3.1 & 10.2 & 81.7 & 13.4 \\
\hline
\end{tabular}

(Source) Unit: GDP - billion US dollars, Population - millions, Kenya's exports and imports- million US dollars. GDP and population from World Development Indicators; Exports and imports sourced from IMF Direction of Trade Statistics. 
Geographic proximity favors Tanzania and Uganda, which are neighboring to Kenya unlike Rwanda and Burundi. Language probably also plays a role as Rwanda and Burundi are French speaking unlike the other three English speaking countries. In terms of political stability Uganda and Tanzania have been relatively stable, especially from the mid-1980s, Rwanda and Burundi have had recent civil wars bringing a death toll of hundreds of thousands of lives during the genocides from 1993 to 1994 . While Rwanda has since achieved stability, to some extent Burundi, on the other hand, experienced civil war until the election of President Pierre Nkurunziza in 2005. In fact, Nkurunziza's decision to run for a third term sparked a fresh wave of civil unrest.

\section{Data}

The survey contains responses from 509 individuals, and the sample's demographic structure in terms of age, education level, income and gender is representative of the population. The survey was conducted in Kenya in June 2015 by Digital Divide Data, one of the major polling agencies in Kenya. Respondents were asked their opinion on which EAC countries should join Kenya in an EAMU. The specific question posed to respondents was :

Statement 1: "In my opinion Kenya should join an EAC currency union that will include the following countries: (1) Uganda (2) Tanzania (3) Rwanda (4) Burundi (5) None of the above."

The respondents were then asked to indicate as many countries as they would like included in the EAMU. Table 2 summarizes the responses to Statement 1: 23.2 percent of the respondents do not support a monetary union while 37.9 percent prefer a partial union of select countries. Of these, 6.5 percent picked one other country to join Kenya in an EAMU, 18.3 percent picked two, and 13.2 percent picked three. The rest (38.9 percent) preferred a full union comprising all five EAC countries. 
Table 2. Level of support for various union sizes anchored around Kenya

\begin{tabular}{|l|c|c|}
\hline \multicolumn{1}{|c|}{ Preferred Union Size } & $\begin{array}{c}\text { Number of } \\
\text { respondents }\end{array}$ & $\begin{array}{c}\text { Percentage of } \\
\text { respondents }\end{array}$ \\
\hline No union: No country picked & 118 & 23.18 \\
\hline Partial union: Any one country picked & 33 & 6.48 \\
\hline Partial union: Any two countries picked & 93 & 18.27 \\
\hline Partial union: Any three countries picked & 67 & 13.16 \\
\hline Full union: All four countries picked & 198 & 38.90 \\
\hline Picked Uganda & 324 & 63.65 \\
\hline Picked Tanzania & 346 & 67.98 \\
\hline Picked Rwanda & 305 & 59.92 \\
\hline Picked Burundi & 237 & 46.56 \\
\hline
\end{tabular}

(Note) Countries picked to join Kenya in an EAMU. Sample size: 509.

Table 3. The desired composition of the EAMU

\begin{tabular}{|l|l|c|c|c|c|}
\hline \multicolumn{2}{|c|}{} & \multicolumn{2}{|c|}{ Without Tanzania } & \multicolumn{2}{c|}{ Tanzania } \\
\cline { 2 - 7 } & $\begin{array}{c}\text { Without } \\
\text { Rwanda }\end{array}$ & Rwanda & $\begin{array}{l}\text { Without } \\
\text { Rwanda }\end{array}$ & Rwanda \\
\hline \multirow{2}{*}{$\begin{array}{l}\text { Without } \\
\text { Uganda }\end{array}$} & $\begin{array}{l}\text { Without } \\
\text { Burundi }\end{array}$ & 118 & 14 & 11 & 13 \\
\cline { 2 - 7 } & Burundi & 0 & 3 & 5 & 21 \\
\hline \multirow{3}{*}{ Uganda } & $\begin{array}{l}\text { Without } \\
\text { Burundi }\end{array}$ & 8 & 12 & 55 & 41 \\
\cline { 2 - 7 } & Burundi & 5 & 3 & 2 & 198 \\
\hline
\end{tabular}


Table 3 shows specific combinations of countries respondents would like included in a monetary union with Kenya. The combinations of countries selected predominantly include the two larger countries (Tanzania and Uganda). Besides the people who do not want a union, combinations that exclude both Tanzania and Uganda were preferred by only 17 (3.3 percent) respondents, while combinations that include either Uganda or Tanzania were preferred by 374 (73.5 percent) respondents. Furthermore, combinations that include at least both Uganda and Tanzania were picked by 296 (58.2 percent) respondents. It is evident that there is a strong preference among Kenyans to include both Uganda and Tanzania (or at least either one of the two) in the union. Furthermore, no respondents picked Burundi as the sole country to join Kenya in a currency union.

To capture the central variable of interest related to gaining international clout, respondents were asked to indicate their level of agreement or disagreement with the following statement:

Statement 2: "The rest of the world will take Kenya and the EAC more seriously if the EAC countries join in a monetary union."

Fifty three percent of the respondents agreed or strongly agreed with Statement 2, while only 20.2 percent disagreed or strongly disagreed (Table 4). The next sections test how those views carried over into foundational preferences for the formation and composition of the union.

The survey also inquired about the earlier monetary union in the EAC. Prior to independence, three of the EAC members_-Kenya, Tanzania, and Ugandaoperated a customs union and a currency board among other things. The East African Currency Board broke down in 1968 and three separate central banks were established ending the first attempt at a monetary union. Hence the survey asks whether Kenyans agreed with the following statement:

Statement 3: "The fact that the EAMU broke up before suggests that a new EAMU is also likely to break up." 


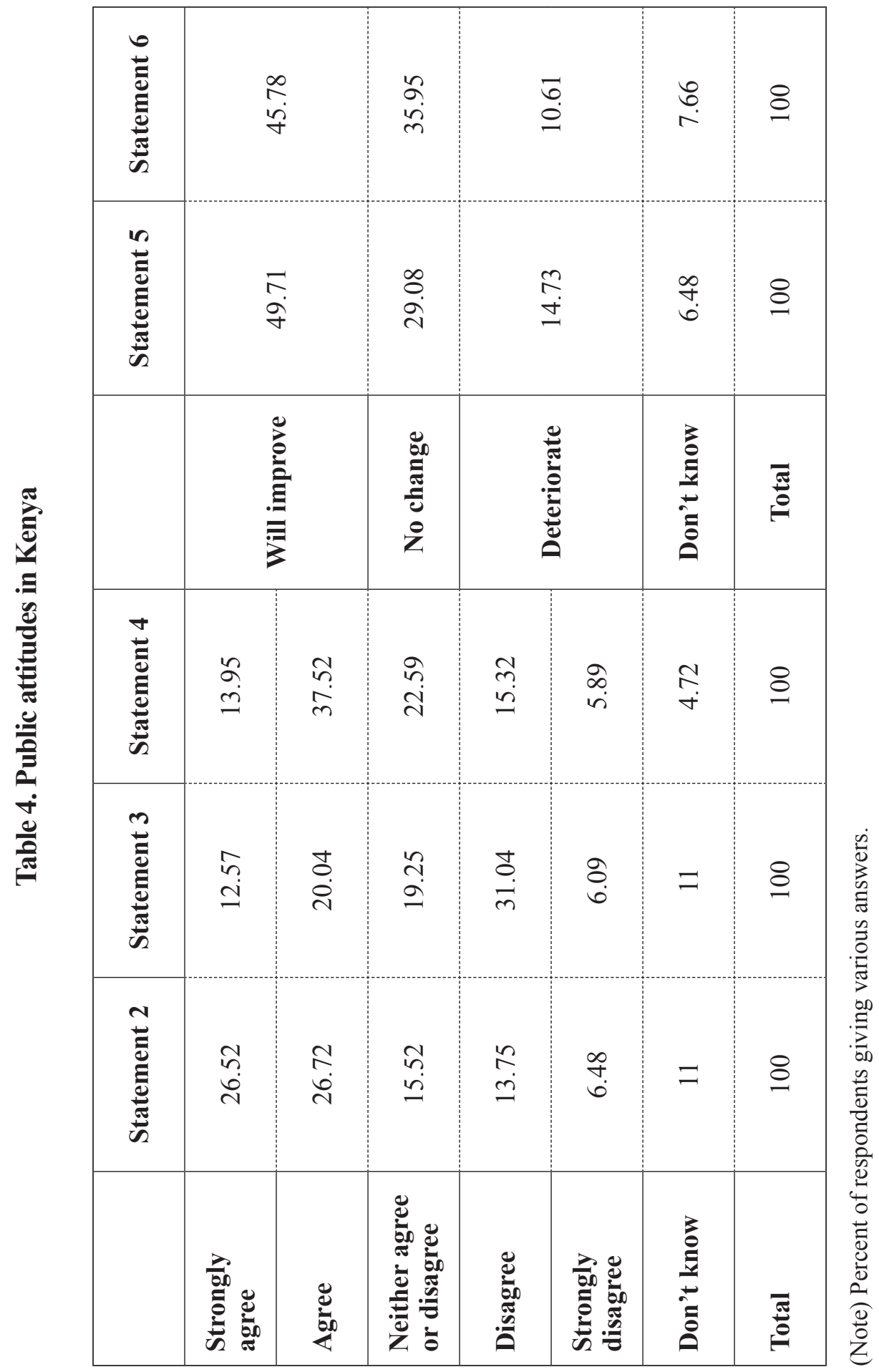


Table 4 shows that the respondents were about evenly split on this issue with one-third who agreed or strongly agreed, and another one-third who disagreed or strongly disagreed. The survey also asked the respondents if they agreed with the following statement:

Statement 4: "I trust the EAC agreement."

Overall, Kenyans seem to trust the EAC agreement with about half of the respondents answering that they agreed or strongly agreed with the statement. In addition, respondents were asked the following two questions, probing expectations of the effect of the monetary union on people's economic wellbeing:

Statement 5: "In your opinion, what will happen to the economic condition of the average Kenyan if Kenya joins the EAMU?"

and

Statement 6: "In your opinion what will happen to your personal economic condition if Kenya joins an EAMU?"

Respondents could answer that the situation would improve, deteriorate, remain unchanged, or that they didn't know. Table 4 shows fairly widespread optimism related to the EAMU with 49.7 percent of the respondents expecting an improvement in the economic situation of the average Kenyan and 45.8 percent expecting an improvement in their own personal economic situation. 


\section{Methodology}

Our first consideration is to assess the likelihood that a respondent is in favor of implementing a monetary union, i.e., that a respondent select at least one country with which Kenya should join in a monetary union:

$$
\begin{gathered}
\operatorname{Pr}(\text { Union=1) }=\Phi(\text { EAMU Taken Seriously, Past Failure, Trust EAC Agreement, } \\
\text { National Benefits, Gender, Education, Age, Income })
\end{gathered}
$$

We used a binary Probit model with robust standard errors. Our key variable of interest is EAMU Taken Seriously that equals 1 for respondents who agreed or strongly agreed with Statement $2 .^{3}$ In terms of control variables, we include Past Failure that equals 1 for respondents who agreed or strongly agreed with Statement 3 and Trust EAC Agreement that equals 1 for respondents who agreed or strongly agreed with Statement 4 . We also add National Benefit that equals 1 if a respondent expected an improvement in the economic situation of the average Kenyan (Statement 5), and 0 otherwise. In robustness tests, we replace National Benefit with Personal Benefit that equals 1 if a respondent expected an improvement in personal economic situation (Statement 6), and zero otherwise.

A number of socioeconomic factors were also included. The direction of the effect of Education (1 for higher education and 0 otherwise) is uncertain as it is likely to promote knowledge about both the costs and benefits of monetary union. Age (entered as age groups) might be associated with weaker support for the union due to lower willingness to take risk while Income (also entered as income groups) may raise support for the union to achieve greater financial stability. A gender variable, Gender (1 for male) may be associated with greater support for the monetary union as female respondents may enjoy

\footnotetext{
${ }^{3}$ See Appendices A1 and A2 for variable definitions, summary statistics, and correlations.
} 
fewer economic opportunities and more limited access to information, thereby lowering their tolerance to risk associated with a major policy change.

As a second step, we assessed whether the pursuit of international clout is associated with a desire for a monetary union of greater size. In principle, larger blocs could project more power. We use an ordered Probit model with robust standard errors and three ordinal dependent variables: Union Size (no union, partial union, and full union), Incremental Union Size (from no union to full union, with one country increment), and Tanzania/Uganda (no union, only Tanzania and Uganda, full union). Again, our primary explanatory variable of interest is EAMU Taken Seriously.

Third, we examined the likelihood of a specific country being picked for inclusion in an EAMU, again using a binary Probit model with robust standard errors. Four empirical models were estimated, one for each country (Tanzania, Uganda, Rwanda, and Burundi). For example, the empirical model to assess the determinants of Tanzania being picked would be of the form:

$\operatorname{Pr}($ Tanzania $=1)=\Phi($ EAMU Taken Seriously, Past Failure, Trust EAC Agreement,

National Benefits, Gender, Education, Age, Income)

We were interested in whether the coefficient estimate on EAMU Taken Seriously had the same magnitude and statistical significance for each of the potential union members. 


\section{Results}

Table 5 shows the estimations of Equation (1) first with a very parsimonious specification in column1 that includes only EAMU Taken Seriously and Past Failure. We then add the variables that measure trust in the EAC and the expected benefits from the monetary union, and in the third column we add demographic variables. The objective is to examine the general support for a monetary union and whether the estimates for the key variable of interest are robust to various model specifications. Indeed, we see that EAMU Taken Seriously is positive and statistically significant in all models suggesting that gaining international clout is an important reason to pursue monetary unification. In terms of the control variables, the failure of the previous integration efforts reduced support for the proposed monetary union, while trust in the EAC institutions strengthened it. Expecting economic benefits from the monetary union also lends support for integration. The demographic variables are, largely, statistically insignificant.

Next, in Table 6 we report the results of the ordered Probit estimations using Union Size, Incremental Union Size, and Tanzania/Uganda as dependent variables to investigate whether gaining international clout is seen to require a larger union with more members. The findings confirm that EAMU Taken Seriously is positive and significant in all models: a larger union is a vehicle for greater international importance. 
Table 5. Public support for the EAMU

(binary Probit results)

\begin{tabular}{|c|c|c|c|}
\hline \multirow{3}{*}{ EAMU Taken Seriously } & \multicolumn{3}{|c|}{ Dependent variable : Union $=1$ or 0} \\
\hline & $1.128 * * *$ & $0.887 * * *$ & $0.915^{* * *}$ \\
\hline & $(0.146)$ & $(0.161)$ & $(0.165)$ \\
\hline \multirow{2}{*}{ Past Failure } & $-0.765 * * *$ & $-0.587 * * *$ & $-0.630 * * *$ \\
\hline & $(0.139)$ & $(0.145)$ & $(0.147)$ \\
\hline \multirow{2}{*}{ Trust EAC Agreement } & & $0.784 * * *$ & $0.798 * * *$ \\
\hline & & $(0.162)$ & $(0.169)$ \\
\hline \multirow{2}{*}{ National benefit } & & $0.810^{* * *}$ & $0.838 * * *$ \\
\hline & & $(0.166)$ & $(0.175)$ \\
\hline \multirow{2}{*}{ Gender } & & & -0.122 \\
\hline & & & $(0.149)$ \\
\hline \multirow{2}{*}{ Education } & & & -0.030 \\
\hline & & & $(0.176)$ \\
\hline \multirow{2}{*}{ Age (26 yrs. to 35$)$} & & & -0.174 \\
\hline & & & $(0.220)$ \\
\hline \multirow{2}{*}{ Age (36 yrs. to 45$)$} & & & 0.151 \\
\hline & & & $(0.252)$ \\
\hline \multirow{2}{*}{ Age (46 yrs. to 55) } & & & $-0.493 *$ \\
\hline & & & $(0.282)$ \\
\hline \multirow{2}{*}{ Age $(\geq 56$ yrs. $)$} & & & -0.208 \\
\hline & & & $(0.293)$ \\
\hline \multirow{2}{*}{ Income $(25000$ to $<50000 \mathrm{Ksh})$} & & & -0.214 \\
\hline & & & $(0.202)$ \\
\hline \multirow{2}{*}{ Income $(50000$ to $<100000 \mathrm{Ksh})$} & & & -0.176 \\
\hline & & & $(0.265)$ \\
\hline \multirow{2}{*}{ Income ( $\geq 100000 \mathrm{Ksh})$} & & & -0.254 \\
\hline & & & $(0.374)$ \\
\hline \multirow{2}{*}{ Constant } & $0.575 * * *$ & -0.008 & 0.273 \\
\hline & $(0.107)$ & $(0.129)$ & $(0.235)$ \\
\hline Observations & 509 & 509 & 509 \\
\hline
\end{tabular}

(Note) Dependent variable: Union = 1 if at least one country is picked for inclusion in the EAMU with Kenya, 0 otherwise. Age: reference group is 18 yrs $\sim 25$ yrs. Income: reference group is $<25000 \mathrm{Ksh}$. Robust standard errors shown in parenthesis. ***, **, * indicates statistical significance at the $1 \%, 5 \%$, and $0 \%$ level, respectively. 


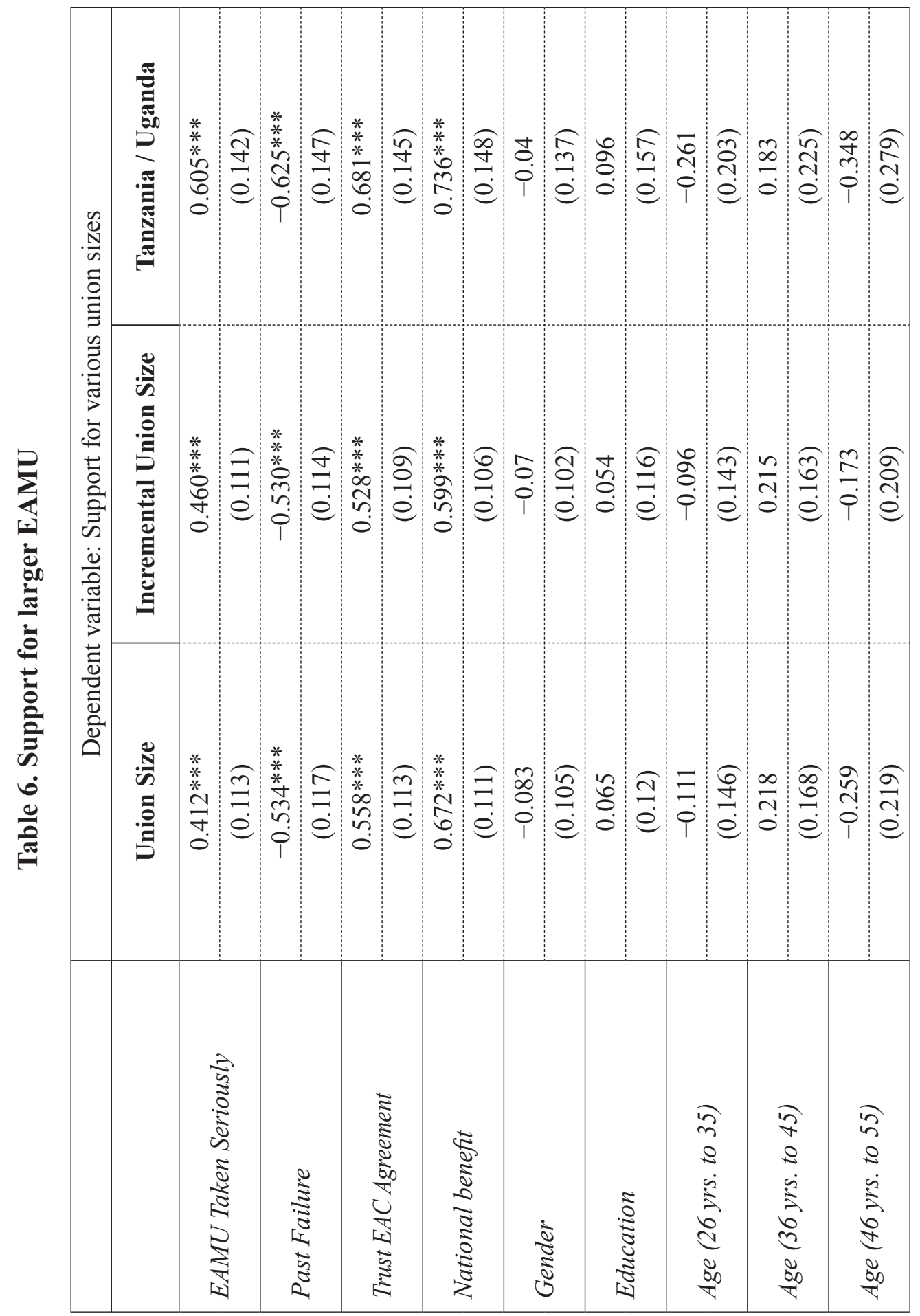




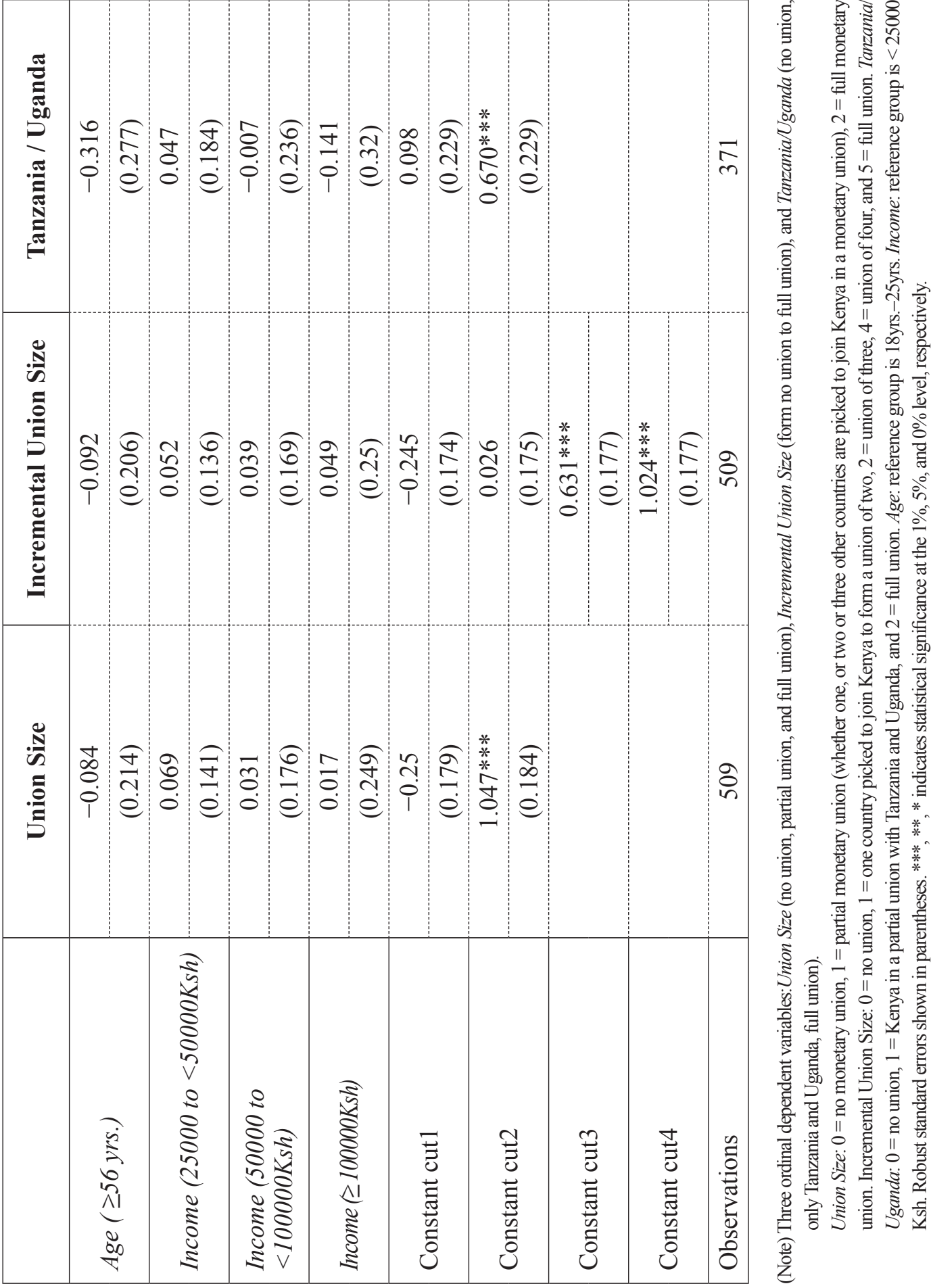


Table 7. Individual countries to join the EAMU

\begin{tabular}{|c|c|c|c|c|}
\hline & \multicolumn{4}{|c|}{ Dependent variable: 1 or 0} \\
\hline & Tanzania & Uganda & Rwanda & Burundi \\
\hline \multirow{2}{*}{ EAMU Taken Seriously } & $0.796 * * *$ & $0.522 * * *$ & $0.431 * * *$ & $0.218^{*}$ \\
\hline & $(0.136)$ & $(0.132)$ & $(0.128)$ & $(0.127)$ \\
\hline \multirow{2}{*}{ Past Failure } & $-0.370 * * *$ & $-0.601 * * *$ & $-0.535 * * *$ & $-0.426 * * *$ \\
\hline & $(0.136)$ & $(0.134)$ & $(0.133)$ & $(0.135)$ \\
\hline \multirow{2}{*}{ Trust EAC Agreement } & $0.567^{* * *}$ & $0.568^{* * *}$ & $0.347 * * *$ & $0.493 * * *$ \\
\hline & $(0.138)$ & $(0.134)$ & $(0.13)$ & $(0.128)$ \\
\hline \multirow{2}{*}{ National benefit } & $0.611^{* * *}$ & $0.540^{* * *}$ & $0.472 * * *$ & $0.540^{* * *}$ \\
\hline & $(0.14)$ & $(0.134)$ & $(0.128)$ & $(0.126)$ \\
\hline \multirow{2}{*}{ Gender } & -0.088 & 0.046 & 0.004 & -0.15 \\
\hline & $(0.131)$ & $(0.126)$ & $(0.12)$ & $(0.119)$ \\
\hline \multirow{2}{*}{ Education } & -0.129 & -0.163 & $0.293^{* *}$ & 0.157 \\
\hline & $(0.149)$ & $(0.146)$ & $(0.137)$ & $(0.135)$ \\
\hline \multirow{2}{*}{ Age (26 yrs. to 35$)$} & 0.033 & -0.145 & -0.178 & -0.055 \\
\hline & $(0.192)$ & $(0.181)$ & $(0.174)$ & $(0.168)$ \\
\hline \multirow{2}{*}{ Age (36 yrs. to 45) } & $0.374^{*}$ & 0.024 & 0.135 & 0.274 \\
\hline & $(0.213)$ & $(0.213)$ & $(0.201)$ & $(0.191)$ \\
\hline \multirow{2}{*}{ Age (46 yrs. to 55) } & -0.001 & -0.171 & -0.26 & -0.027 \\
\hline & $(0.26)$ & $(0.25)$ & $(0.232)$ & $(0.238)$ \\
\hline \multirow{2}{*}{ Age ( $\geq 56$ yrs.) } & 0.019 & -0.072 & -0.165 & -0.168 \\
\hline & $(0.257)$ & $(0.249)$ & $(0.263)$ & $(0.255)$ \\
\hline \multirow{2}{*}{${ }^{2}$ Income (25000 to $\left.50000 K s h\right)$} & -0.273 & 0.239 & 0.099 & 0.02 \\
\hline & $(0.171)$ & $(0.168)$ & $(0.16)$ & $(0.157)$ \\
\hline \multirow{2}{*}{ Income $(50000$ to $<100000 \mathrm{Ksh})$} & -0.06 & -0.19 & 0.109 & 0.112 \\
\hline & $(0.221)$ & $(0.21)$ & $(0.2)$ & $(0.199)$ \\
\hline \multirow{2}{*}{ Income $(\geq 100000 \mathrm{Ksh})$} & -0.261 & 0.222 & 0.271 & -0.151 \\
\hline & $(0.32)$ & $(0.312)$ & $(0.306)$ & $(0.287)$ \\
\hline \multirow{2}{*}{ Constant } & -0.184 & -0.111 & $-0.334^{*}$ & $-0.669 * * *$ \\
\hline & $(0.212)$ & $(0.206)$ & $(0.199)$ & $(0.195)$ \\
\hline Observations & 509 & 509 & 509 & 509 \\
\hline
\end{tabular}

(Note) Dependent variable: 1 if the given country is picked for inclusion in the EAMU, 0 otherwise. Age : reference group is 18yrs. 25yrs. Income : reference group is $<25000 \mathrm{Ksh}$. Robust standard errors shown in parentheses. ***, **, * indicates statistical significance at the $1 \%, 5 \%$, and $0 \%$ level, respectively. 
Table 7, however, shows that not all potential members are viewed similarly. The table shows the results of the Probit estimations (Equation 2) for each of the four countries considered for inclusion in a monetary union with Kenya. Column 1 shows the factors determining the choice of Tanzania as a member of the union. Similarly, columns 2, 3, and 4 consider the support for Uganda, Rwanda, and Burundi, respectively. The coefficient on the clout variable, EAMU Taken Seriously, is positive and statistically significant in all cases implying that those who strongly agree or agree that the world will take Kenya and the EAC more seriously if they join in a monetary union are more likely to pick a country to join in EAMU. However, the magnitude of the coefficients declines from 0.796 (for Tanzania) to 0.218 (Burundi). Furthermore, the coefficient for Burundi is significant at the $10 \%$ level only compared to the coefficients for the other countries, which are significant at the $1 \%$ level. This suggests that the effect of the clout variable on the likelihood of a country being picked is not necessarily similar across the EAC countries. In short, while a union is desirable for the purposes of gaining international clout and a larger union is preferred for that purpose, not all potential member countries are favored equally.

Note that in Table 6 and in Table 7, as in Table 5, the expected economic condition of the average Kenyan, National Benefit, and the trust variable, Trust EAC Agreement, are positive and statistically significant as expected. Skepticism due to earlier failed monetary union, Past Failure, is also negative and significant as expected. The age, gender, education, and income variables are largely insignificant. In unreported estimations, we replaced National Benefit with Personal Benefit in all estimations and obtained very similar results. 


\section{Conclusion}

We employed unique survey data from Kenya to show that gaining greater international power is a motivating factor in pursuing monetary unification in East Africa. Several studies has shown that small states form regional blocs for that purpose, but they have not provided direct evidence that the public recognizes and expresses this benefit ahead of the formation of a monetary union. The views of the wider public are important, since few other policiesif any - have such sweeping consequences as abandoning the national currency and delegating monetary policy to a supranational body.

The survey shows that people are generally in favor of the monetary union for the purpose of gaining greater international standing, however, other factors are significant as well. Specifically, expected improvements in the economy and trust in the East African Community (EAC) agreement increase the support of the monetary union, while the failure of a previous East African Monetary Union (EAMU) raises concerns about the viability of the current attempt.

We also show that Kenyans are not indifferent about which other countries will enter the union. While Tanzania and Uganda are clearly favored, Rwanda and, particularly, Burundi seem to raise concerns. Hence, in addition to setting economic convergence criteria to be met by member countries, it appears sensible to include political stability criteria as well. Nonetheless, it is worth reiterating that these are results of public perception from one member country alone. It is recommended to extend the study to assess the public's perception from the other EAC member countries, too.

Received 31 January 2018, Revised 30 March 2018, Accepted 28 April 2018 


\section{References}

Andriamananjara, Soamiely, and Maurice Schiff. M. "Regional cooperation among microstates." Review of International Economics, 9, (2001): 42-51.

Blomberg, Stephen, Jeffry Frieden, and Ernesto Stein. "Sustaining fixed exchange rates: The political economy of currency pegs in Latin America. ” (2001)

Buigut, Steven. "The fear of exclusion and public support for a multilateral monetary union." International Journal of Monetary Economics and Finance, 3, no.2, (2010): 112-125.

Buigut, S. "Trade effects of the East African Community Customs Union: hype versus reality." South African Journal of Economics, 84(3), (2016): 442-439.

Buigut, Steven, and Neven T. Valev, N. "Benefits from mutual restraint in a multilateral monetary union." World Development, 37(3), (2009): 585-594.

De Grauwe, Paul. "The political economy of the Euro." Annual Review of Political Science, 16, (2013): 153-170.

European Commission. The European Union explained: Economic and monetary union and the euro. European Commission, Directorate-General for Communication Citizens information 1049 Brussels BELGIUM. DOI: 10.2775/19208. (2014)

Feldstein, Martin. "The political economy of the European economic and monetary union: political Sources of an economic liability." Journal of Economic Perspectives, 11(4), (1997): 23-42.

Forlati, Chiara. "On the benefits of a monetary union: does it pay to be bigger?" Journal of International Economics 97(2), (2015): 448-463. 
Frankel, Jeffrey A., and Andrew K. Rose." The endogeneity of the optimum currency area criteria." Economic Journal 108(449), (1998): 1009-25.

Frieden, Jeffry, Piero Ghezzi, and Ernesto Stein. "Politics and exchange rates: A cross-country approach to Latin America." in the Currency Game: Exchange Rate Politics in Latin America (Baltimore: Johns Hopkins University Press). (2001)

Goldstein, Andrea, and Njuguna S. Ndung'u. "Regional integration experience in the Eastern African region." (2001)

Guillaume, Dominique M., and David Stasavage."Improving policy credibility: is there a case for African monetary unions?" World Development 28(8), (2000): 1391-1407.

Hazlewood, Arthur. "The end of the East African Community: What are the lessons for regional integration schemes?" Journal of Common Market Studies 18(1), (1979): 40-58.

Kimenyi, Mwangi Samson and Karl Kuhlmann. "Africa union: Challenges and prospects for regional integration in Africa."The Whitehead Journal of Diplomacy and International Relations 13, (2012): 7-27.

Lepetit, L., Rugemintwari, C., and Strobel, F. "Monetary, financial and fiscal stability in the East African Community: Ready for a monetary union?" The World Economy, 38(8), (2015): 1179-1204.

Maloney, J. \& Macmillen, M. "Do currency unions grow too large for their own good?" The Economic Journal, 109(458), (1999): 572-587.

Masson, Paul R. "New monetary unions in Africa." Economie internationale 3 (2006): 87-105. 
Nnyanzi, John Bosco, Peter Babyenda, and John Mayanja Bbale. "Regional Economic Integration and Tax Revenue: East African Community." Journal of Economic Integration (2016): 932-967.

Orphanides, Athanasios. "The euro area crisis: Politics over economics." Atlantic Economic Journal 42, no. 3 (2014): 243-263.

Rose, Andrew K., and Eric Van Wincoop. "National money as a barrier to international trade: The real case for currency union." American Economic Review 91 no. 2 (2001): 386-390.

Schiff, Maurice. "Small states, micro states, and their international negotiation and migration." Journal of economic integration (2014): 430-449.

Whalley, John. "Why do countries seek regional trade agreements?." In The regionalization of the world economy, p. 63-90. University of Chicago Press, 1998. 


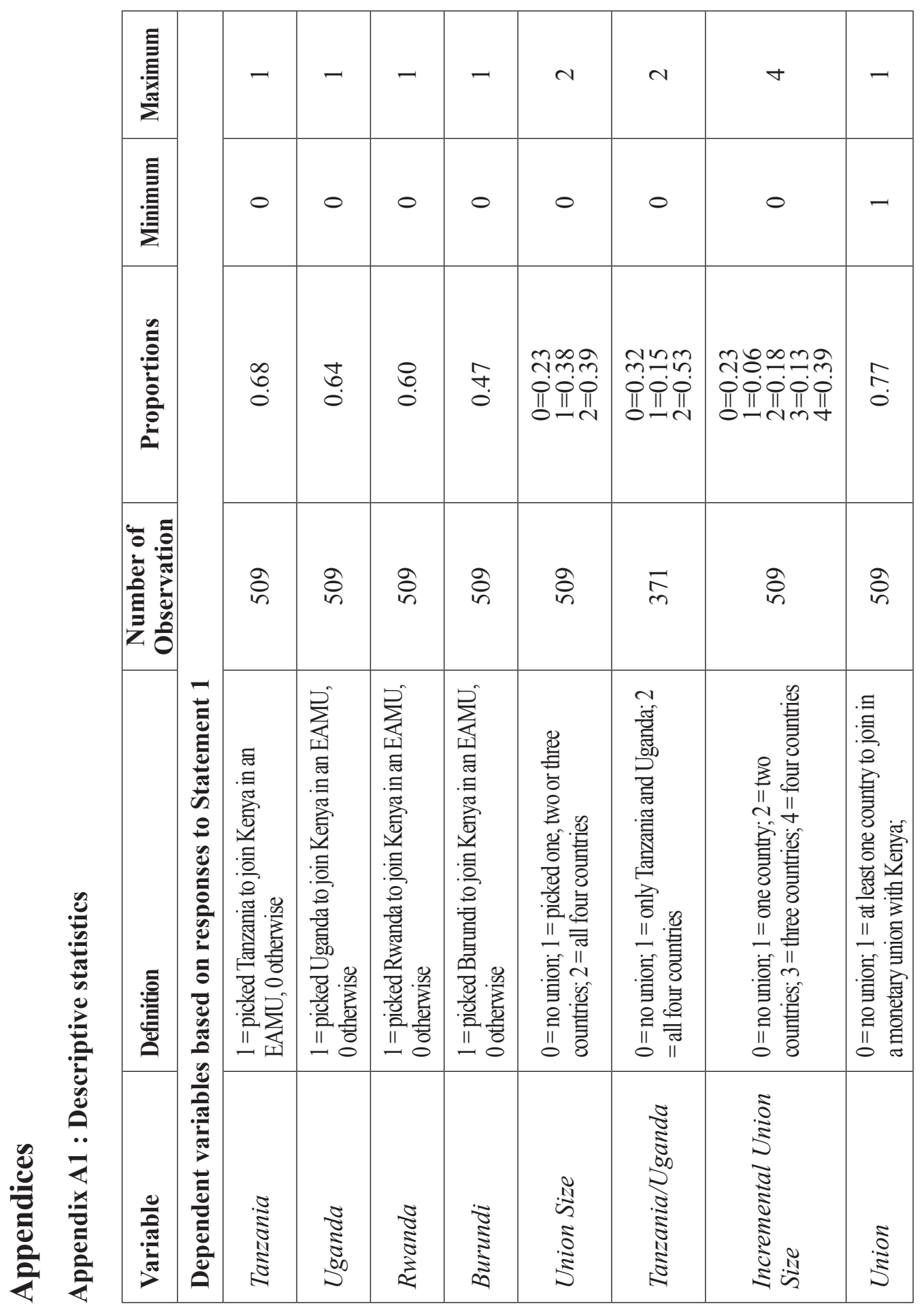




\begin{tabular}{|c|c|c|c|c|c|c|c|c|c|c|}
\hline 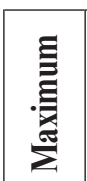 & & - & - & - & - & - & $n$ & - & - & $\nabla$ \\
\hline 䒠 & & 0 & 0 & 0 & 0 & 0 & - & 0 & 0 & - \\
\hline 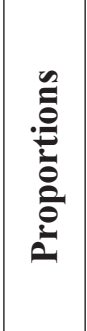 & & $\begin{array}{c}\widetilde{n} \\
\tilde{n} \\
0\end{array}$ & 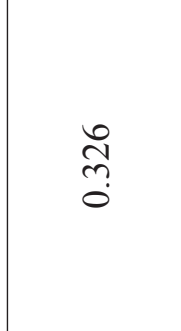 & $\frac{n}{n}$ & $\stackrel{\hat{a}}{\dot{\sigma}}$ & $\stackrel{\infty}{\stackrel{\infty}{+}}$ & 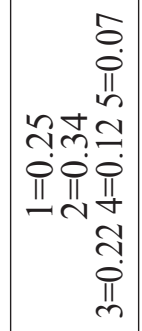 & 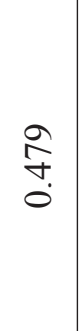 & त̄ & 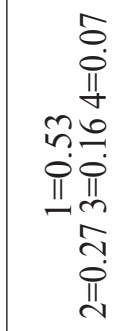 \\
\hline 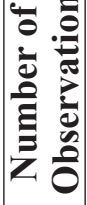 & & ठे & हे & iे & के & ठे & oे & 今े & iे & oे \\
\hline 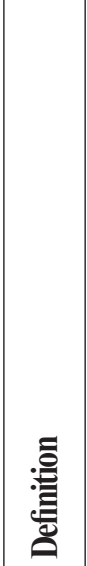 & 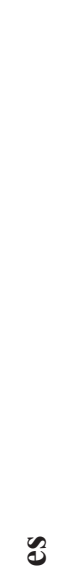 & 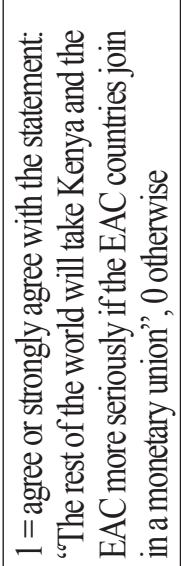 & 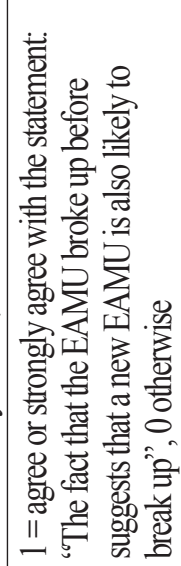 & 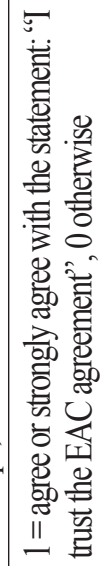 & 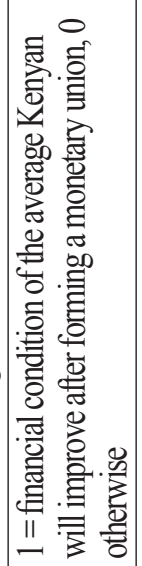 & 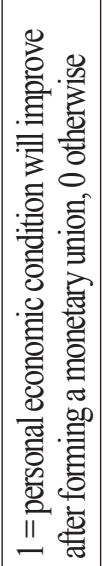 & 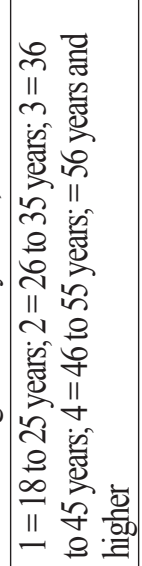 & 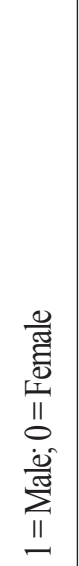 & 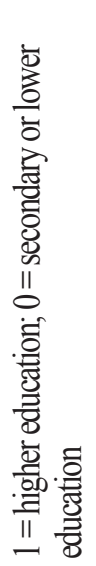 & 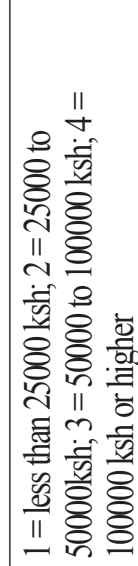 \\
\hline 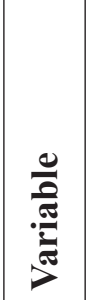 & 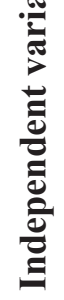 & 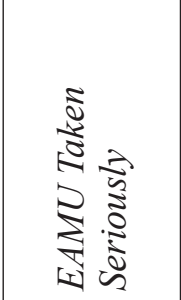 & 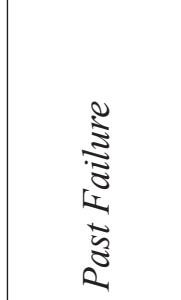 & 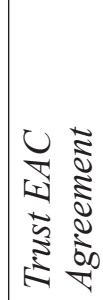 & 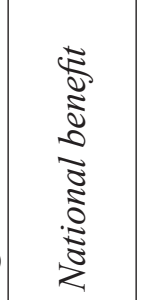 & 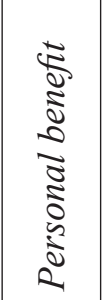 & $\nabla^{\infty}$ & $\frac{\mathbb{\Xi}}{\mathbb{\Xi}}$ & 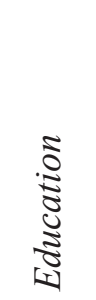 & 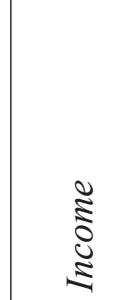 \\
\hline
\end{tabular}




\begin{tabular}{|c|c|c|c|c|c|c|c|c|c|}
\hline 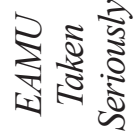 & & & & & & & & & $\underset{8}{8}$ \\
\hline$\frac{\tilde{3}}{3} \cdot \frac{0}{\tilde{z}}$ & & & & & & & & ஜ & \begin{tabular}{l}
\multirow{0}{*}{} \\
ñ \\
$\stackrel{1}{0}$ \\
1
\end{tabular} \\
\hline 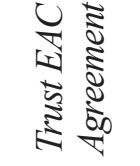 & & & & & & & $\stackrel{8}{8}$ & 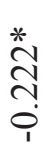 & 華 \\
\hline 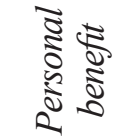 & & & & & & ஓ & 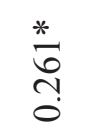 & $\begin{array}{l}\stackrel{*}{O} \\
\stackrel{\text { ஸे }}{0} \\
\text { 1 }\end{array}$ & 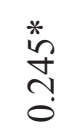 \\
\hline 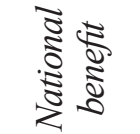 & & & & & 8 & \begin{tabular}{l}
\multirow{2}{*}{} \\
ñ \\
$n$ \\
0
\end{tabular} & $\begin{array}{l}\frac{*}{\infty} \\
\stackrel{\infty}{0} \\
\vdots\end{array}$ & 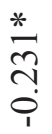 & $\begin{array}{l}\text { *ै } \\
\text { ते } \\
\text { ò }\end{array}$ \\
\hline 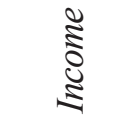 & & & & $\stackrel{8}{8}$ & $\begin{array}{l}8 \\
\text { g. }\end{array}$ & $\frac{n}{?}$ & 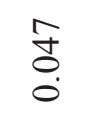 & \begin{tabular}{l}
0 \\
\multirow{0}{0}{} \\
0 \\
0
\end{tabular} & $\stackrel{N}{\hat{0}}$ \\
\hline 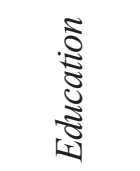 & & & 8 & $\frac{*}{\stackrel{*}{n}}$ & $\begin{array}{l}n \\
0 \\
0 \\
0\end{array}$ & $\begin{array}{l}0 \\
0 \\
0 \\
0\end{array}$ & $\begin{array}{l}n \\
0 \\
0\end{array}$ & $\begin{array}{l}0 \\
0 \\
0 \\
0\end{array}$ & $\begin{array}{l}0 \\
0 \\
0 \\
0\end{array}$ \\
\hline$\frac{\bar{d}}{\frac{1}{8}}$ & & ஜ & $\begin{array}{l}0 \\
8 \\
0 \\
0\end{array}$ & $\begin{array}{l}n \\
\vdots \\
0\end{array}$ & $\begin{array}{l}\overrightarrow{2} \\
0 \\
0\end{array}$ & $\frac{\infty}{0}$ & তิ & $\begin{array}{l}\dot{0} \\
\stackrel{8}{0} \\
0\end{array}$ & $\begin{array}{l}\text { đठ } \\
\stackrel{0}{0} \\
0\end{array}$ \\
\hline$\infty$ & 8 & $\begin{array}{l}0 \\
\stackrel{n}{0} \\
0\end{array}$ & 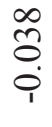 & $\stackrel{*}{\stackrel{*}{n}}$ & $\begin{array}{l}0 \\
\stackrel{n}{0} \\
0\end{array}$ & 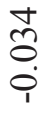 & 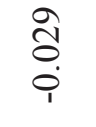 & \begin{tabular}{l}
$n$ \\
\multirow{0}{0}{} \\
$\dot{0}$
\end{tabular} & $\stackrel{7}{\circ}$ \\
\hline & $\underset{\nabla}{\infty}$ & $\frac{\grave{d}}{\frac{1}{0}}$ & 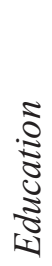 & 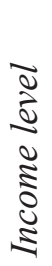 & 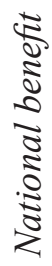 & 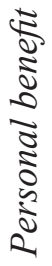 & 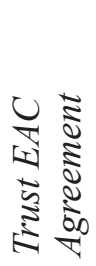 & 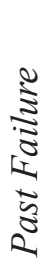 & 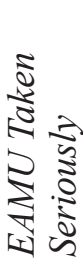 \\
\hline
\end{tabular}

